\title{
Sea ice, climate change, and community vulnerability in northern Foxe Basin, Canada
}

\author{
J. D. Ford ${ }^{1, *}$, W. A. Gough ${ }^{2}$, G. J. Laidler ${ }^{3}$, J. MacDonald ${ }^{4}$, C. Irngaut $^{4}$, K. Qrunnut $^{4}$ \\ ${ }^{1}$ Department of Geography, McGill University, 805 Sherbrooke St. West, Montreal, Quebec H3A 2K6, Canada \\ ${ }^{2}$ Department of Physical and Environmental Sciences, University of Toronto at Scarborough,1265 Military Trail, \\ Scarborough, Ontario M1C 1A4, Canada \\ ${ }^{3}$ Department of Geography and Environmental Studies, Carleton University, 1125 Colonel By Drive, B349 Loeb Building, \\ Ottawa, Ontario K1S 5B6, Canada \\ ${ }^{4}$ Hamlet of Igloolik, Nunavut X0A 0L0, Canada
}

\begin{abstract}
The Arctic is undergoing rapid climatic and environmental change, most notably in the spatial extent and thickness of the sea ice. Inuit communities in the Canadian Arctic are directly affected by these changes, with dramatic change in sea ice conditions documented in recent years. We use a case study from the Inuit community of Igloolik to examine the processes and conditions shaping human vulnerability to sea ice change. In 2006, the ocean froze 3 to 4 wk later than normal, with little remnant ice during the summer. Igloolik residents described this state of sea ice as anomalous, and Inuit observations were consistent with instrumental sea-ice data. We examined how community members experienced and responded to the anomalous ice conditions of 2006, using our analysis of this perceptual/behavioral data as a lens for exploring vulnerability and its determinants. Inuit observations shed light on the implications of such ice conditions for human use of this arctic environment, including reduced ability to procure traditional food. Effects on the community were exacerbated by other climate-related conditions and non-climatic stresses, including increasing fuel prices and longer-term socio-cultural trends. The case study also indicates significant adaptive capacity: anomalous ice years are increasingly becoming the norm and there is evidence that social learning and responsive local institutions are reducing the physical risks of using the ice in a changing climate. Climatic extremes documented in 2006 are projected to be the new mid-century norm as a result of anthropogenic climate change. The case study therefore offers a baseline for examining potential future vulnerabilities.
\end{abstract}

KEY WORDS: Climate change - Vulnerability - Adaptation - Climate hazards - Inuit · Igloolik · Nunavut $\cdot$ Sea ice $\cdot$ Retrospective analysis $\cdot$ Mixed methods

\section{INTRODUCTION}

Of the changes documented in the Arctic environment in recent years, changes in sea ice stand out prominently (Kerr 2007, Stroeve et al. 2007). For the Arctic as a whole, passive microwave imagery shows a decrease in September ice extent of $\sim 7.7 \%$ per decade for the period 1979-2004 and a sharp reduction in multi-year ice (Stroeve et al. 2005). Studies based on submarine sonar records indicate a de- crease in ice thickness, while surface observations and satellite imagery demonstrate later ice freeze-up and earlier break-up (Johannessen et al. 2004, Meier et al. 2006, Moore 2006, Overland \& Wang 2007). Anomalous ice conditions are concentrated in recent years of the record, particularly in 2002-2007 (Stroeve et al. 2007). Sea ice change is occurring in the context of a suite of changes in the Arctic environment documented over the last $30 \mathrm{yr}$, and is widely believed to be at least partially attributed to 
anthropogenic emissions of greenhouse gases (Holland et al. 2006, Stroeve et al. 2007).

Changing sea ice conditions have wide-ranging implications for physical and human systems in the Arctic (Huntington et al. 2007, Ford in press). Sea ice is important in the ecology of the Arctic, providing a habitat for animals, playing a crucial role in shaping climate and weather, and acting as an essential platform for seasonal transportation and culturally important resource harvesting activities (i.e. fishing and hunting) (ACIA 2005, Hovelsrud et al. 2008). For humans, the sea ice is a dynamic and unforgiving environment affecting their ability to harvest and travel safely. George et al. (2004) and Norton \& Gaylord (2004), for instance, documented episodes in the last 50 yr in Barrow, Alaska, where unexpected break-up of shorefast ice threatened Iñupiat whale hunters with loss of livelihood and life. Moreover, as the climate changes, indigenous knowledge of the sea ice is challenged and confidence to use it is reduced; accidents due to unusual and unexpected ice conditions have been reported across the Arctic and evidence indicates that climate change is already impacting Arctic residents (ACIA 2005, Gearheard et al. 2006, Huntington et al. 2007, Keskitalo 2008, Ford in press). While many of the impacts of changing sea ice conditions are negative, research has also documented benefits including a longer open-water hunting season and reduced exposure to extreme cold (Ford et al. 2008b). Climate models predict sea ice change to continue into the foreseeable future (ACIA 2005, IPCC 2007a). All model runs in the Intergovernmental Panel on Climate Change (IPCC) Fourth Assessment Report, for example, project a shrinkage in future sea ice cover (IPCC 2007b), leading the Panel to conclude with a high level of confidence that sea ice extent will continue to decrease this century.

Considering the susceptibility of sea ice to a changing climate, it is widely believed that human communities will be largely negatively affected by climate change (Corell 2006, Huntington et al. 2007, IPCC 2007a, Hovelsrud et al. 2008). Inuit political leaders have even argued that changing ice conditions due to anthropogenic emissions violate fundamental human rights of Inuit (see e.g. the 2005 petition submitted by S. Watt Cloutier/The Inuit Circumpolar Conference, www.ciel.org/Publications/ICC_Petition_7Dec05.pdf). Research to evaluate the potential impacts of sea ice change, however, has only recently become a major focus of the literature. Significant gaps remain in understanding the vulnerability of Arctic communities to climate change (Duerden 2004, ACIA 2005, Gearheard et al. 2006, Huntington et al. 2007, Ford 2008, Furgal \& Prowse 2008, Moore \& Huntington 2008). Improved understanding of human vulnerability and determinants thereof should therefore be a research priority, given the projections of rapid climate change in Arctic regions (ACIA 2005).

We use a case study from the Inuit community of Igloolik, Nunavut, in the Canadian High Arctic, to identify and explore some of the key processes and conditions shaping vulnerability to sea ice change. Specifically, we examine how community members experienced and responded to anomalous ice conditions in 2006, using 2006 as a lens for understanding determinants of vulnerability. We begin by describing the study area, explaining the methodology used in the research, and then characterizing the sea ice conditions in 2006 and their departure from long-term norms. We then explore how the community was affected by the extreme ice conditions, identify adaptive responses, and characterize processes and conditions shaping vulnerability. We finish by examining the potential implications of future climate change.

\section{STUDY AREA}

Foxe Basin is a shallow, $550 \mathrm{~km}$ long and $360 \mathrm{~km}$ wide basin north of Hudson Bay, Canada, located between Baffin Island and Melville Peninsula in the territory of Nunavut (Fig. 1). Sea ice dominates the surrounding waters for much of the year, with most of the Basin characterized by sea ice that is $1 \mathrm{yr}$ old or less (first year ice). Open water often appears in the northwestern part of the Basin in May (around Labrador Narrows), with ice break-up occurring on average near the end of July (Laidler et al. 2009). Sea ice gradually melts, with the Basin becoming ice-free in September. After the first year ice has melted in summer, northern Foxe Basin frequently experiences old ice (including second year and multi-year ice) that flows through Fury and Hecla Strait from the Gulf of Boothia. Ice begins to form in early October and freeze-up usually occurs by mid to late October. The region to the southeast of Igloolik forms a non-linear area of open water surrounded by sea ice in late spring. Sometimes, this open water continues to grow in size until ice break-up occurs. On other occasions, the open water closes up before the final ice break-up. Since most of the sea ice in Foxe Basin is first year ice, it rarely exceeds $1.5 \mathrm{~m}$ in thickness.

There are 2 communities along the shores of northern Foxe Basin: Igloolik and Hall Beach (Fig. 1). Igloolik, the focus of this study, is a coastal community of 1538 people (95\% Inuit) (StatsCanada 2006) located on Igloolik Island near the eastern entry of Fury and Hecla Strait $\left(69^{\circ} 23^{\prime} N\right.$, $\left.81^{\circ} 48^{\prime} \mathrm{W}\right)$. Located off the east coast of Melville Peninsula, the island and the mainland have a relatively flat topography and can be classified as having a polar tundra climate (Köppen 

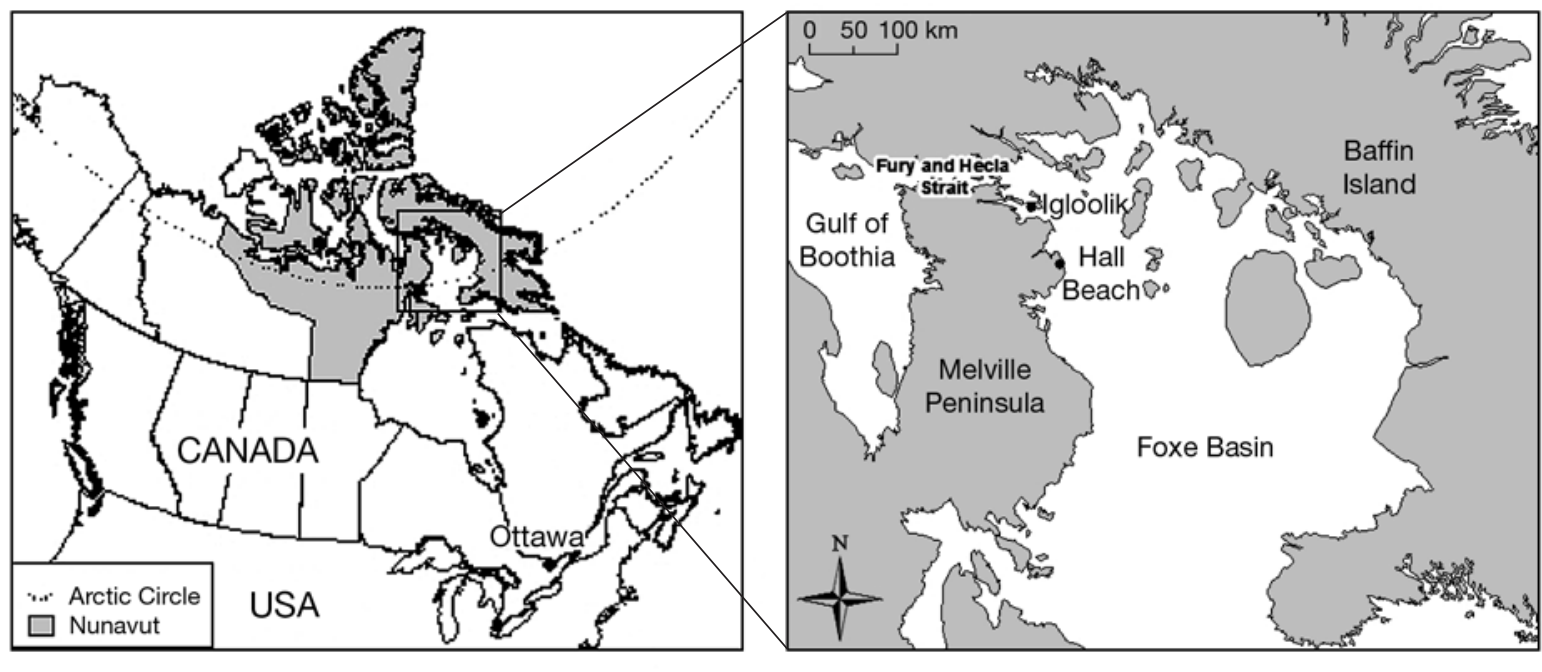

Fig. 1. Foxe Basin and the community of Igloolik

classification). June, July and August are the warmest months when temperatures are above freezing. February is the coldest month of the year with a mean temperature of $-31^{\circ} \mathrm{C}$.

The harvesting of marine and terrestrial mammals is widely practiced in Igloolik, as in most Nunavut communities (Chan et al. 2006, Kuhnlein \& Receveur 2007). 'Country food' (traditional food harvested by Inuit) contributes a significant portion to the community's nutritional intake, although younger generations appear to have a diminished taste for locally harvested produce, preferring instead store-bought processed food (Ford et al. 2006b). The ice acts as an essential hunting platform from which walrus Odobenus rosmarus, ringed seal Phoca hispida, bearded seal Erignathus barbatus and polar bear Ursus maritimus are harvested. The frozen ocean surface also provides an important transportation medium, allowing access to the mainland in the south (Melville Peninsula) and Baffin Island in the North, which comprise important caribou Rangifer tarandus hunting grounds, Arctic char Salvelinus alpinus fishing lakes, and community connections to Hall Beach.

Foxe Basin is at the forefront of climate change (Ford 2008, Ford et al. 2008a,b). Many community members in Igloolik have noted anomalous ice conditions since the mid 1990s, and data from Canadian Ice Service (CIS) and Environment Canada weather stations correspond with Inuit observations, showing a pattern of later ice freeze-up, earlier break-up, and altered ice dynamics (Laidler et al. 2009). Many important hunting and travel activities are dependent on the condition of the physical environment, and changing conditions have largely had negative implications to date, although benefits have also been noted (Ford et al. 2006b, Ford et al. 2008a,b).

\section{METHODOLOGY}

\subsection{Vulnerability analysis}

Vulnerability can be defined as the 'capacity to be wounded'; it is a measure of the susceptibility to harm in response to a stimulus or stimuli (Smit \& Pilifosova 2003, Smit \& Wandel 2006). In this paper, we use the model of Ford \& Smit (2004) and Ford et al. (2006a) to examine the processes and conditions shaping vulnerability to sea ice conditions in Igloolik. This model conceptualizes vulnerability as a function of exposure sensitivity to climate-related risks and the adaptive capacity to deal with those risks. Exposure sensitivity reflects the susceptibility of people and communities to climate-related conditions that represent risks, while adaptive capacity reflects a community's potential or ability to address, plan for, or adapt to these risks (Ford et al. 2006a). In this conceptualization, vulnerability at a community level is viewed as being conditioned by social, economic, cultural, political and climatic conditions and processes operating at multiple scales over time and space, which affect community exposure sensitivity and adaptive capacity. This is consistent with other conceptualizations of vulnerability in the climate change literature (Turner et al. 2003, Duerden 2004, Schröter et al. 2005, Fussel \& Klein 2006, Smit \& Wandel 2006, Smit et al. 2008, Berrang Ford et al. 2009). Through detailed place-based case studies, these processes and interactions can be documented across time and space and their determinants identified.

Retrospective analysis of community vulnerability to climatic change, extremes, and variability is widely used in the literature to identify vulnerability determinants, and provide a baseline for assessing vulnerability under conditions of future climate change (Glantz 
1988, 1996, Duerden 2004, Duerden \& Beasley 2006, Leary et al. 2007, Huntington et al. 2008, McLeman et al. 2008, van Aalst et al. 2008). The IPCC (2007a), for instance, used the European heatwave of 2003 to illustrate potential climate change vulnerabilities in Europe. Similarly, Hamilton et al. $(2000,2003)$ examined the influence of environmental changes on modern fisheries-dependent societies in Greenland, shedding light on processes that may shape how communities experience and respond to future climate change. Here we examine how community members in Igloolik experienced and responded to anomalous ice conditions in 2006, focusing on use of the ice for resource harvesting and travel. This enables us to (1) explore how community members experience and manage climate-related risks, (2) identify processes and conditions that determine the availability, efficacy, and success of adaptations, (3) develop a greater understanding of how social and biophysical processes shape vulnerability, and (4) establish a range of possible societal responses to future change. Moreover, given the similarity of ice conditions in 2006 with general trends projected for the Igloolik region by global climate models (Dumas et al. 2006), we believe it is particularly worthwhile to identify and characterize some of the actual processes and conditions shaping vulnerability and adaptability.

\subsection{Methods}

We use mixed methods that combine qualitative and quantitative approaches to: (1) identify and characterize sea ice conditions which posed risks to community members in 2006, (2) characterize how community members experienced and managed these risks, and (3) identify processes and conditions that influenced exposure sensitivity and determined the availability, efficacy, and success of adaptations. Data collection for 2006 is supported by previously published research by the authors (Ford et al. 2006a,b, Laidler \& Ikummaq 2008, Laidler et al. 2009, Ford in press), which add historical context to temporal trends in sea ice conditions, exposure sensitivity, and adaptive capacity.

\subsubsection{Instrumental data}

Ice charts: To characterize the nature of sea ice conditions in 2006 and assess temporal trends, sea ice data were obtained in chart form from the CIS. These charts are derived from both surface observation and satellite imagery, with ice information relayed in the form of fractional ice coverage of the ocean surface on a maximum value of 10 , which can be equated to a percent- age of surface ice cover. The satellite data derives from infrared and visible light sensors on weather satellites as well as microwave technology on other satellites such as RADARSAT. Charts are produced on a weekly basis when northern waters are potentially navigable (May to November), but less frequently during winter. Thus, they are useful in evaluating sea ice conditions and variability during transitional stages, and summer months (Laidler et al. 2009).

CIS ice charts were used in this study to determine break-up and freeze-up dates and ice conditions for the Igloolik region. Two sea ice cover thresholds were used to determine the freeze-up: 5/10 sea ice coverage, which is commonly used to define freeze-up reflecting a ship-navigable water threshold (Gagnon \& Gough 2005b); and 9/10 sea ice coverage, which approximates sea ice that can be navigated by community members on snowmobile or on foot (Laidler et al. 2009). For break-up, 5/10 ice coverage was used as the threshold, which is consistent with other work (Gough et al. 2004, Gagnon \& Gough 2005a, Laidler et al. 2009). Ice charts were also visually analyzed to characterize the nature of the ice during the summer open-water period.

Ice chart data exist from 1982 to the present. The visual presentation of charts has evolved during this time period but they are annotated using a consistent methodology for the representation of ice conditions. Charting is also available from 1969 to 1982 using a different scheme for the representation of ice conditions. An ice cover of $9 / 10$ is easily identified from these older charts, but not a cover of 5/10. Thus, the freeze-up data reported here extends from 1969 to 2006 for the 9/10 threshold, but the 5/10 time series for both freeze-up and break-up only span 1982 to 2006. Moreover, the data from 1982 to 2006 were used for the more detailed statistical analysis, reflecting the higher level of confidence in the more recent data. Linear regression was used to detect trends in freeze-up and break-up timing according to date, with a $t$-statistic calculated on the slope to determine statistical difference from zero (see Laidler et al. 2009 for more detail).

Nunavut Research Institute data: Sea ice data collected by Nunavut Research Institute (NRI) employees in Igloolik between 1985 and 2006 were also utilized to determine the timing of ice freeze-up and break-up. The data refer to ice conditions in Turton Bay, Igloolik, which is a relatively sheltered location adjacent to, and thus visible from, the community. In this dataset, freeze-up is defined as occurring when the ice is solid across the bay and can hold the weight of an adult (but not a snowmobile). Break-up is defined as occurring when the ice in Turton Bay is floating free (no longer landfast) and is sufficiently open to permit unhindered canoe and motorboat traffic between the settlement and Igloolik Point ( 4.5 km away). 


\subsubsection{Local expertise}

The local spatial and broad temporal scales of Inuit knowledge of the sea ice were used here to help interpret and expand instrumental data of sea ice conditions in 2006, facilitate analysis of change over time, and characterize processes shaping local vulnerability. Inuit populations possess detailed, location-specific knowledge of the sea ice, which is built up through personal observation and experience, and from experiences shared among members of the community (Laidler 2006). However, not all Inuit have similar levels of understanding of specialized topics; active hunters and experienced elders are typically the community members who know the most about past and present sea ice conditions and marine issues. For such hunters, successful and safe sea ice travel and hunting depends on personal understanding of the combined influences of winds, currents, and weather on ice formation and dynamics (Nelson 1969, Aporta 2002, Krupnik \& Jolly 2002, Laidler \& Elee 2008, Laidler \& Ikummaq 2008, Laidler et al. 2008). Therefore, observations of sea ice conditions and changes are inherent in hunters' ongoing, long-term use of the sea ice, and comprise a holistic, sophisticated, and comprehensive understanding of the complexities of marine, wildlife, and atmospheric conditions (Laidler 2006). It is thus important and valuable to consult, and work with, local sea ice experts to characterize local sea ice conditions, and better understand the implications of long-term sea ice trends on sea ice use and local livelihoods (Krupnik \& Jolly 2002, Gearheard et al. 2006, Meier et al. 2006, Laidler et al. 2008).

Specifically for Igloolik, efforts to document and convey this rich local sea ice knowledge has already been undertaken by Aporta (2002) and Laidler \& Ikummaq (2008). Here, we are building upon this foundation in order to better understand recent sea ice trends and their socio-economic influences. Incorporating local experiences and expertise is imperative in understanding what instrumental data means in 'real terms', as well as in learning alternative ways to understand, monitor, and characterize changes (McCarthy et al. 2005). However, we acknowledge that the complexities of understanding sea ice through the regular long-term use and cultural practices of Inuit can never be fully conveyed. While attempting to comprehend the points of convergence and divergence between local and instrumental observations can be problematic due to their differing scales, methods, and underlying epistemologies (Cruikshank 2001, Nadasdy 2003, Peters 2003, Furgal et al. 2006, Laidler 2006, Bates 2007), there is great local interest in making Inuit expertise and experiences known to scientists. And without local partnerships and contributions, instrument-based studies of climate or environmental change cannot be meaning- fully translated into on-the-ground implications, vulnerability assessments, or adaptive strategies (McCarthy et al. 2005, Furgal et al. 2006, Bates 2007). Therefore, we put forward this range of contributions of local expertise as a complement to instrumental data, as well as to provide essential insights into, and expansions of, numerical trends that can serve to: (1) improve our understanding of the changes recorded; (2) question the results of scientific sea ice monitoring; and (3) expand interpretations of change based on indicators of greatest importance to community members who rely on ice for transportation, food, and livelihood.

Focus groups: To document Inuit knowledge of sea ice conditions in 2006 and to examine exposure sensitivity and adaptive capacity to sea ice risks, 7 focus group discussion sessions were conducted. To guide the discussion, an outline of key themes to be covered was used as opposed to a list of questions to ask. This allowed participants to concentrate on ice conditions and trends they considered important, and to extend discussion beyond the nature of the ice to the many other factors that influence how Inuit experience the sea ice and their ability to respond to changes in this environment. Focus groups were undertaken with the help of local researchers, and were conducted in both Inuktitut and English. For preliminary verification and validation, clarification questions were asked throughout the focus group discussions when necessary. After each session, the key points raised were reviewed with the local researchers. The sample of participants was obtained from local residents interviewed in previous research (Ford et al. 2006b, Laidler \& Ikummaq 2008, Laidler et al. 2009). Extra weighting was given to the selection of older community members and those actively using the ice to make the description of change over time and of various dimensions of vulnerability possible.

Interviews: Six key informant interviews were conducted with experienced land and resource use managers, including the wildlife officer, the chairperson of the local Hunters and Trappers Association, and the senior administrative officer of the Hamlet. Questions asked during these interviews varied depending on context, but generally sought to examine the nature of sea ice conditions in 2006 and characterize impacts on the community as viewed by local officials. All interviews were in English. Key informant interviews were also used to establish reliability and consistency, allowing findings from the focus group discussions to be compared with other accounts.

The research described in this paper also draws upon 64 in-depth, semi-structured interviews that were conducted with a cross-section of community members between 2002 and 2006 (see Ford et al. 2006b, Laidler \& Ikummaq 2008, Laidler et al. 2009). The interviews covered a number of topics relating to sea ice use and 
change over time. The research also draws upon interviews contained in the Igloolik Oral History Project (IOHP), which is a database started in 1986 containing over 500 interviews with local residents on a variety of topics. The information in the IOHP captures lived experience and oral history spanning the 20th century which, in conjunction with the interviews and focus group discussions conducted by the authors, provides a baseline from which to evaluate and compare sea ice conditions, vulnerability and adaptability in 2006.

Qualitative analysis: The focus group transcripts and key informant interviews were entered into QSR NVivo, a software package designed to organize, handle, and facilitate the analysis of qualitative data. The data were analyzed using thematic content analysis to create common groups or categories describing the nature of sea ice conditions, impacts, adaptation, and vulnerability in 2006 (see Ford 2006b).

\section{SEA ICE EXTREMES IN NORTHERN FOXE BASIN 2006}

\subsection{Fall freeze-up}

\subsubsection{Freeze-up timing}

In Igloolik, the ocean normally freezes and becomes usable for hunting activities and transportation in mid to late October (Laidler et al. 2009). Records kept by the NRI for the period 1985-2006, show an average freeze-up date on 22nd October. For the period 1969-2006, data from CIS ice charts show the average date at which the ocean is $9 / 10$ frozen to be the on 26th October; while data from 1982-2006 show the average date at which the ocean is $5 / 10$ frozen to be on 21st October. In 2006, the CIS data shows $9 / 10$ freeze-up on 6th November (Fig. 2), which is $11 \mathrm{~d}$ later than normal, and 5/10 freeze-up to have occurred $16 \mathrm{~d}$ later than normal. NRI records show freeze-up to have occurred on 5th November in 2006. This is the second latest freeze-up on the NRI record after 1998, when a freeze-up date of 7 th November was recorded. In the CIS dataset, 1998 also had the latest freeze-up recorded on 16th November. It is noteworthy that 1998 was a particularly strong El Nino year, with average global and Arctic temperatures significantly exceeding the norm. In the CIS dataset, the $9 / 10$ freeze-up in 2002 and 2003 were also observed to have occurred later than that in 2006, occurring on 10th and 11th November, respectively (Fig. 2).

The late freeze-up in 2006 is also captured in the following local observations:

'This is the year [the ocean has] been really, really late in freezing up. It has been later than I ever remember. The reason we call this month Tusaqtuut is because this is the time [when] everything is frozen and communication between families would be easier at this time .... but we're still not allowed to go straight [to the mainland] because the ice is very dangerous [and] thin.' (A. Taqqaugak, Dec 2006)

'If it had been earlier like before in my youth, the ice would have set over [in October] and hunters would have been hunting over a month ago. But they haven't started yet because the ice hasn't frozen over.' (A. Ulayuruluk, Dec 2006)

'This is the latest [that the ocean] has ever frozen! This is the first time I have ever known it to freeze this late.' (D. Aqiaruq, Dec 2006)

Local descriptions of a late freeze-up and departure from the long-term norm are consistent with the instrumental data. However, according to focus group participants, the freeze-up in 2006 was described as the latest in living memory, occurring in late November. The instrumental dataset indicates that while freezeup in 2006 was very late, it occurred in early November and was not the latest on record. Divergence between the instrumental data and Inuit observations could be

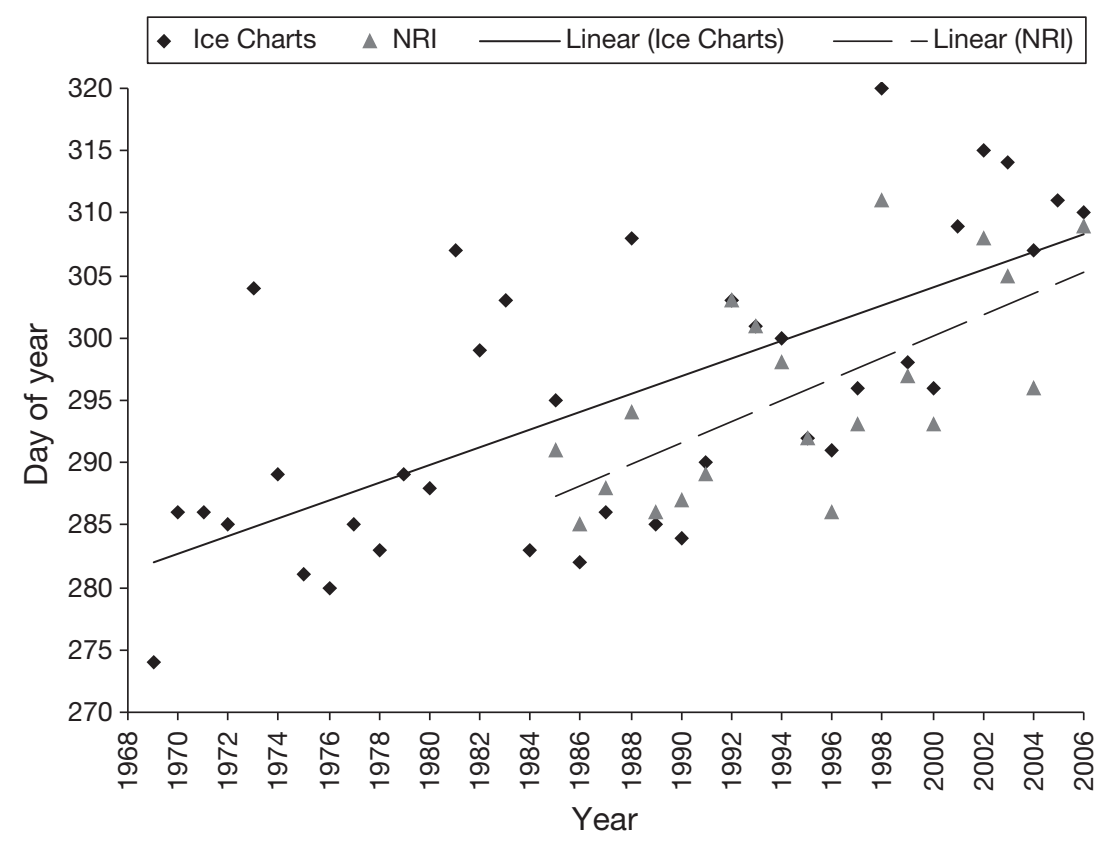

Fig. 2. Times series of freeze-up dates from Canadian Ice Service (CIS) ice charts using a 9/10 ice coverage definition (1969-2006) and Nunavut Research Institute (NRI) data (1985-2006). The trends for both CIS and NRI data are statistically significant $\left(\mathrm{p}<0.01\right.$ ), with corresponding slopes of 0.70 and $0.83 \mathrm{~d} \mathrm{yr}^{-1}$ (modified from Laidler et al. 2009) 
due to differences in how freeze-up is defined and measured, and indicates that both data sources can compliment each other (see Riedlinger \& Berkes 2001). Such nuances may also account for differences between local observations of changing conditions and instrumental datasets noted in other contexts.

Firstly, the NRI dataset defines freeze-up as occurring when the ice can support the weight of an adult. This date is not revised if the ice deteriorates after the initial freeze-up date, as it did in 2006. Hunters described being able to use the ice in the first week of November when below freezing temperatures at the end of October created conditions for freeze-up: temperatures dropped by $4^{\circ} \mathrm{C}$ to a low of $-7^{\circ} \mathrm{C}$ on $31 \mathrm{st}$ October and reached a low of $-19^{\circ} \mathrm{C}$ on 3rd November. At this time, 9/10 of the ocean became frozen (Fig. 3). Participants then described a combination of rising temperatures and heavy snowfall making the ice too dangerous to use from mid to late November. This is captured in the temperature record of the Igloolik weather station, with temperatures increasing to a high of $-3^{\circ} \mathrm{C}$ on 15 th November and persisting for a week. On 19th and 20th November, $12.9 \mathrm{~cm}$ of snow fell. Ice charts produced on the 20th show that the ocean to the south of Igloolik decreased from being $9 / 10$ to $7 / 10$ frozen before returning to being 9/10 frozen on 27 th November (Fig. 3). An ice coverage of $7 / 10$ is unlikely to be suitable for safe use.

Differences in definition are also important in explaining the difference between hunters' descriptions of freeze-up and the CIS data. The ice chart analysis defines freeze-up according to ice coverage and connectivity, i.e. $>5 / 10$ coverage, or $>9 / 10$ coverage. These are necessary but not sufficient conditions for Inuit use of the ice. Inuit also assess ice thickness and stability when deciding if the ice is safe to use, and judge freeze-up based on these additional ice dimensions (which are not measured by the ice charts) (see George et al. 2004, Laidler \& Ikummaq 2008). After the initial freeze-up in early November 2006, the ice was deemed by Inuit too dangerous to use until late November due to rising temperatures and snowfall, which slowed the thickening and stabilization of the ice. This is partially documented in the ice chart data which shows ice decreasing to $7 / 10$ coverage in mid November.
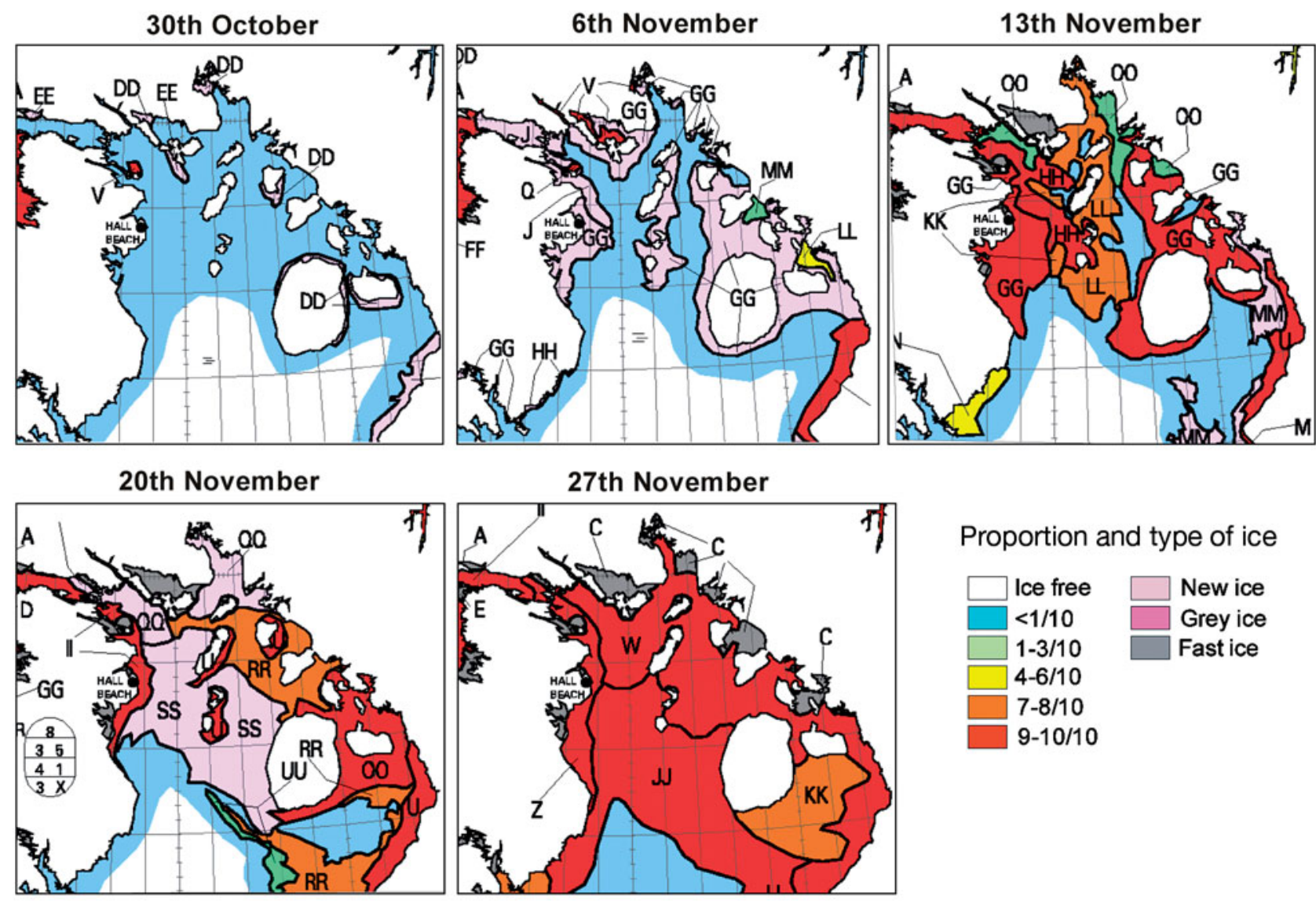

Proportion and type of ice

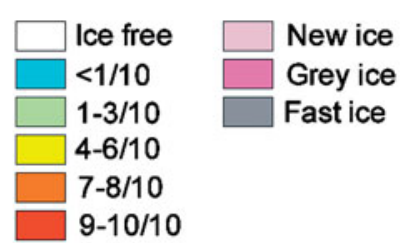

Fig. 3. Progression of freeze-up in fall 2006 as depicted in Environment Canada's CIS ice charts. Note the change of 9-10/10 ice coverage to new ice between November 13th and 20th. The letter codes on the ice charts refer to detailed descriptions and are individualised for each map: further information can be found at http://ice-glaces.ec.gc.ca/ 
Secondly, differences in spatial and temporal scale of measurement may also account for the different freeze-up dates between Inuit observations and instrumental data. In fall, many community members take only short trips on the ice to access mainland hunting areas. The ice in such areas is of key importance, yet ice charts have poor resolution at this scale. Inuit are also observing the ice on a daily basis, compared to ice charts which take a snapshot of ice conditions once a week between May and November. It is possible, for instance, that ice cover went below $7 / 10$ between 13th and 20th November but ice data were not obtained at this time in the CIS charts. Ultimately, whether the freeze-up in 2006 was the latest on record is not the key point here; what is important is that both Inuit knowledge and instrumental data indicate that freeze-up was significantly later in 2006 than the long-term average, thereby providing an opportunity to investigate how local people were affected by and responded to sea ice extremes. Importantly, the comparison of Inuit knowledge and instrumental data on sea ice conditions highlights that crucial sea ice indicators are not necessarily those measured by instruments (i.e. quality vs. quantity). This is particularly pertinent in the development of sea ice hazard forecasting systems that is now underway in some Inuit regions.

Interestingly, sea ice in the Gulf of Boothia to the northwest, and upwind of Igloolik, was observed to have broken up during September 2006. Normally at least $19 \%$ of the Gulf never breaks up (Barber \& Iacozza 2004). Therefore, 2006 is the first year on record when this has occurred. This would change the nature of the ice passing through Fury and Hecla Strait into northern Foxe Basin, providing an upwind moisture and heat source for Igloolik, and is one possible explanation for the late freeze-up in 2006.

\subsubsection{Freeze-up speed}

Coincident with the late freeze-up, the speed of freeze-up-defined locally as the time taken by ice to allow safe travel once it starts forming - was described as being particularly slow. However, this trend is not evident in the ice chart data, which indicates rapid progression from 5/10 to $9 / 10$ frozen cover on the same day in 2006. Similar to discrepancies between Inuit and ice chart data in freeze-up timing, the lack of convergence in freeze-up speed may be due to a combination of ice deterioration after initial freezing, differences in freeze-up definition, and type of measurement. In previous research in Igloolik, local people have noted slower freeze-up progression in recent years, which is consistent with the instrumental data revealing a statistically significant delay in progression from 5/10 to 9/10 frozen cover in the period 1982-2005 (Laidler et al. 2009).

\subsubsection{Long-term freeze-up trends}

Sea ice anomalies documented in 2006 are consistent with a trend of changing ice conditions observed in northern Foxe Basin since the mid to late 1990s. Laidler et al. (2008) documented a statistically significant delay ( $95 \%$ confidence) of freeze-up (9/10 definition) in the Igloolik region of $\sim 0.7 \mathrm{~d} \mathrm{yr}^{-1}$, or 1 wk per decade, based on data spanning 1969 to 2005 (Fig. 2). Detailed analysis of these years indicates that the bulk of the change has occurred since 1990. In the CIS data between 1969 and 1997, November freeze-up occurred only twice, but it occurred 7 times from 1998-2006. Likewise, Inuit in the community report observing later freeze-up beginning in the mid to late 1990s (Ford et al. 2006a, Laidler et al. 2009).

\subsection{Spring break-up}

Previous research in Igloolik has documented earlier sea ice break-up of $0.6 \mathrm{~d} \mathrm{yr}^{-1}$ for the years 1982-2005 (Laidler et al. 2009). The timing of the ice break-up in 2006, however, deviated little from the mean recorded in the instrumental data. The NRI data show break-up to have occurred on 19th July in 2006, compared to a mean of 22nd July between 1985-2006. Data from the CIS (defining break-up as occurring at $5 / 10$ coverage) show ice break-up in 2006 to have occurred on 3rd August, the same day as the 19822006 average. Similarly, Inuit in the focus groups described the 2006 break-up as following normal progression and timing.

\subsection{Summer}

The open-water season in Igloolik lasts from late July/early August until early to mid October. During this period, walrus are usually found resting on floating ice, particularly in regions to the northeast and southeast of Igloolik, and are hunted by Inuit (Anderson \& Garlich-Miller 1994). Floating ice comprises ice that is not attached to land and is constantly moved by ocean currents and winds. It typically includes ice that is defined as $1 / 10$ coverage in the CIS charts and, in many instances, is composed of small pans of ice. It may, however, also include ice of greater coverage, but usually less than the 5/10 threshold for boat navigation. In 2006, focus group participants noted an 
absence of floating ice in summer walrus hunting areas in northern Foxe Basin as indicated in the following accounts:

'We had a very rough walrus hunting season because the ice was gone! Usually the ice that's here is coming from Labrador Narrows [and] it's usually loaded with ice. This year there was no ice. It came in from this direction [from Labrador Narrows] and then went.' (A. Taqqaugak, Dec 2006)

'For the walrus hunt this year there [was] no ice at all, that was the problem. July and August there's no ice at all. .... [Rowley Island] is walrus area, it always has ice, but this year there was none, no ice.' (L. Uttak, Dec 2006)

Elders characterized the summer ice conditions in 2006 as being unprecedented. Indeed, in 64 interviews conducted in previous climate change research in Igloolik and in interviews analyzed in the IOHP, there is little indication of abnormalities in ice presence and resulting walrus availability of this magnitude, during summer. Unusual ice conditions in summer are clearly visible in the CIS ice charts. In ice charts analyzed from 1982-2005, Foxe Basin typically becomes completely ice free by mid September, with a slow disappearance of remnant ice after break-up. August is typically characterized by large areas of floating ice. However, ice charts for the years 2001, 2004, 2005, and 2007, show large areas of Foxe Basin with $\leq 1 / 10$ ice coverage (Fig. 4). It is noteworthy that in these years, except for 2004, the ice broke up earlier than the 1982-2005 average. Summer ice cover in these charts can therefore be considered below average. In 2006, however, there was an almost complete absence of ice in Foxe Basin, with small areas of 1/10 ice cover surrounding the community and to the northwest around Fury and Hecla Straight, and in the southeast around Prince Charles Island (Fig. 4). August ice coverage of this nature was not detected in the charts for other years analyzed here. Importantly, there was no ice cover visible in August 2006 in locations where Igloolik Inuit normally hunt walrus on floating ice, corroborating Inuit description.

\section{VULNERABILITY AND ADAPTABILITY IN 2006}

Sea ice extremes in 2006 provide a lens from which to explore community exposure sensitivity to climaterelated risks and characterize adaptive capacity. Dimensions of vulnerability are evident in the food system. Community adaptability is also evident in adaptive responses minimizing the physical risks of using the ice. 30th August 2004

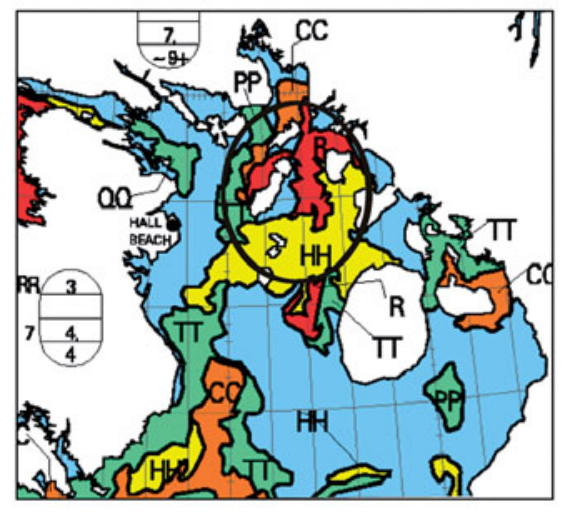

Proportion of ice

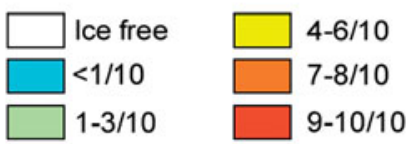

29th August 2005

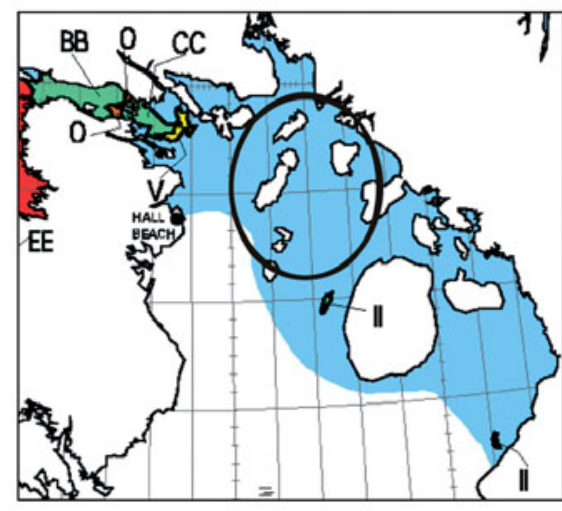

27th August 2007

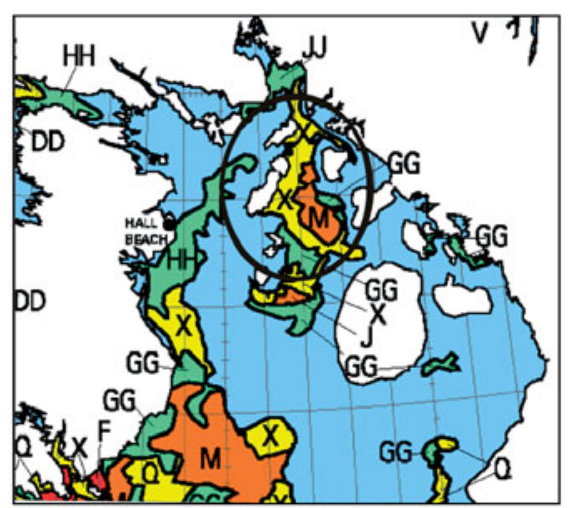

28th August 2006

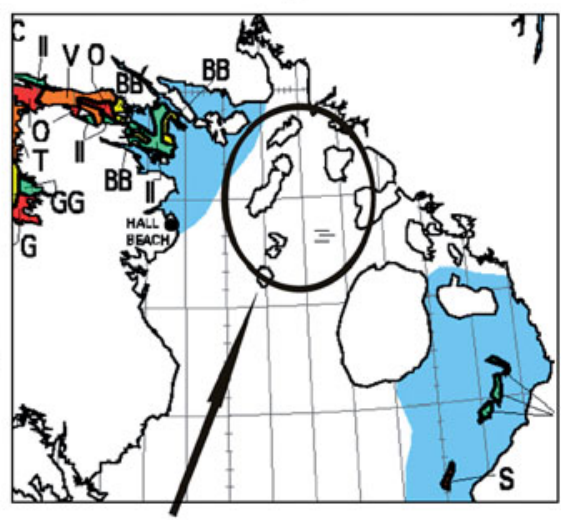

Summer walrus hunting areas

Fig. 4. End of August ice coverage in Foxe Basin as depicted in Environment Canada's CIS ice charts. Note the unusually low ice cover in the entire Basin in 2006. Charts selected are from years with earlier than normal ice break-up which further underscores the abnormality of 2006. The letter codes on the ice charts refer to detailed descriptions and are individualised for each map: further information can be found at http://ice-glaces. ec.gc.ca/ 


\subsection{Sea ice conditions and food system vulnerability}

\subsubsection{Exposure sensitivity}

Focus group participants described sea ice conditions in summer and fall 2006 as constraining their ability to procure country food. It was noted that rapid disappearance of the ice after break-up and absence of floating ice reduced their ability to hunt walrus in northern Foxe Basin during the summer. Participants described walrus as being located further south in Foxe Basin, around Prince Charles Island, where there was 1/10 ice coverage (Fig. 4). This was well beyond the range of many local hunters. Walrus that remained in northern Foxe Basin congregated along the shoreline making them difficult to find and harder to hunt (see Anderson \& GarlichMiller 1994). This affected the food system by decreasing the availability of walrus meat. It was particularly problematic for elders and more mature community members for whom walrus is an important food source in summer and fall, providing a well balanced source of nutrients, vitamin A, and protein (Kuhnlein et al. 1996). Fermented and aged walrus meat (igunak) meanwhile, is considered a local delicacy, the consumption of which is important in establishing and re-affirming community social relations. Limited walrus meat, especially during early summer when the meat is cached for ageing, resulted in limited production of igunak.

'This year we have no igunak [aged walrus]. We go out hunting but come back without walrus because there [is] no ice ..... because the hunt has been bad we have only been able to hunt just for today. We haven't done any caching of walrus meat. This is the first time in my life that I have gone without aged walrus meat.' (A. Ulayuruluk, Dec 2006)

'There's hardly been any Igloolik people hunting walrus this year [in the summer] because there has been no ice at all.' (H. Paniaq, Dec 2006)

'I normally have 8 caches of walrus meat in the summer, this year I only had one.' (Anonymous, December 2006)

Young Inuit in this study and in previous research, however, openly admitted to a disinclination to eat walrus due its strong and acquired taste, not to mention the hard work required to harvest the animal. Indeed, many elders have been complaining about the demise of walrus hunting in the last few decades, specifically from the perspective of cultural preservation. Therefore, young Inuit were less affected by limited walrus availability in 2006. This indicates the importance of non-climatic factors in shaping exposure sensitivity to climate change, extremes and variability. Indeed, negative trends from a cultural perspective, may reduce exposure sensitivity to climate changean issue addressed later in the article.
During fall, sea ice is widely used for travel to caribou hunting grounds and char fishing lakes on the mainland (Melville Peninsula), as well as a platform for hunting ringed seals. Ringed seals are hunted in small pockets of open water that remain as the ice is freezing and also in bays and points of land where cracks open up (Laidler et al. 2008). Participants articulated that the slow freeze-up in 2006 limited their ability to travel to the mainland because the ice was too thin and dangerous to use until late November, except for a short period at the beginning of the month. This significantly reduced people's ability to hunt seals on the ice and travel to hunt caribou and char, reducing the availability of food from these animals. Thus, the widespread appeal and importance of these species in the local diet increased exposure sensitivity due to limited availability as indicated in the following accounts:

'This fall has been long because we spend a lot of time on [Igloolik] island. Usually we go out hunting earlier in the fall but we haven't been able to go to the mainland for a while. We have not been able to get new meat because of this ...... So there has been hardly any new meat over fall.' (N. Qamaniq, Dec 2006)

'[It has been] bad, bad. Not [many] seals [and we] couldn't go out caribou hunting. When the snow comes we couldn't go out hunting caribou for 2-3 weeks because of the thin ice.' (H. Ittusardjuat, Dec 2006)

Even when the ice became safe to use in late November, it was not until early December that the ice reached a thickness capable of supporting direct travel to the mainland. These routes normally start being used for travel to char fishing lakes and for caribou hunting between late October and early November. The resulting detours added travel time and in some cases doubled the travel distance, and hence cost, thereby limiting access to those with time and/or sufficient financial resources.

\subsubsection{Adaptive capacity}

Due to the reduced access to and availability of wildlife in summer and fall, participants in the study reported having to purchase more store food to meet their dietary needs. For elders, active hunters and those with a strong connection to the land-based economy, switching to store-bought food was not considered an equal trade-off: country food are preferred because they are believed to be healthier, fresher, better tasting, and have cultural significance. Additionally, for those who rely on country food, switching to store-bought food was not always an option due the high cost of commercial goods in the North and limited access to financial means. Participants stated that those who did not have enough money to purchase 
food in 2006 had to rely on family members to share store food, used the food bank, and some reported going without food for a couple of days. Even for those who could afford store food, the additional stress placed on household income by reliance on purchased food has reinforced the negative impacts of ice conditions by adding financial burden to the cost of other climate adaptations, including having to use more gasoline to hunt and travel longer distances.

In previous years, the sharing of country food has helped to uphold access despite environmental stress (Ford et al. 2006b). It was noted that sharing was important in 2006, supplementing the diet of those who were unable to hunt or were not successful in procuring country food. For example, even though the summer walrus hunt was limited, those who were successful described sharing the meat with those who 'craved walrus meat' but had none, and those who had country food stored during fall reported sharing with others. Sharing was described as mostly occurring in the extended family unit but also with friends. In summer and fall in 2006, sharing networks were significantly stressed. However, there was too little walrus and caribou meat in the summer and fall to satisfy demand.

Flexibility in hunting behavior has also previously enabled Inuit in Igloolik to manage fluctuations in wildlife availability (Ford et al. 2006b), and was utilized in 2006 to maximize hunting success. In summer 2006, hunters searched the northern Foxe Basin coastline looking for walrus in areas where they are not usually found. Others went further south looking for walrus. This resulted in partial success for some hunters, although the extra gasoline costs entailed were prohibitive for many (especially considering high gasoline prices). Participants also described catching bearded seal in summer when walrus were scarce. Bearded seal, however, is largely used for dog food in Igloolik. Even those who searched extensively for walrus were unable to catch enough to offset reduced availability.

\subsubsection{The role of multiple stressors}

Other climatic conditions were reported to magnify the vulnerability of the food system to anomalous sea ice conditions in 2006. Heavy, powdery snow on the mainland in November, believed locally to be due to warm temperatures, made caribou difficult to hunt. Powdery snow also made it hard to use snowmobiles, especially when transporting harvested animals, and increased use of gasoline, thereby affecting the amount of harvest brought back to the community. Caribou have also migrated away from the Igloolik region in recent years (they were found $130 \mathrm{~km}$ to the southwest of Igloolik in 2006). This trend, which is part of a nat- ural long-term cycle, increased the difficulties of access associated with powdery snow. In fall 2006, it was therefore difficult to offset reduced marine mammal harvest with caribou meat. Thus, climate-related conditions reduced the ability to switch species hunted, which is a key adaptive response to environmental stress documented previously in Igloolik and in Inuit communities across the Arctic (Berkes \& Jolly 2001, Ford et al. 2006a, Furgal \& Seguin 2006, Nickels et al. 2006, Riewe \& Oakes 2006). Non-climatic conditions, including higher oil and commodity prices, and high baseline food insecurity, also exacerbated the implications of sea ice conditions in 2006, and are assessed in detail elsewhere (Ford in press).

\subsection{Sea ice and physical risk}

\subsubsection{Exposure sensitivity}

October and November are widely regarded as the most dangerous times of the year for using the sea ice. Non-uniform freezing rates can hide areas of open water. Air pockets can form under the ice, thereby increasing the risk of falling in and making such locations more prone to breaking off. Where ocean currents are strong, the ice can often remain thin and unstable until later in the year, and in some locations, all year (Laidler et al. 2008). The dangers related to sea ice travel in early fall are compounded if snow falls on thin ice, as it insulates the ice underneath, promoting ice melt from the heat of the ocean (and movement of currents). As experienced locally, the late and gradual freeze-up in 2006, combined with snowfall on ice in mid November, increased the danger of using the ice. It was reported that hunting equipment were damaged in accidents where people fell through the ice.

'Because of the condition of the ice [this fall] a couple of snowmobiles have been lost .....' (A. Taqqaugak, Dec 2006)

'It was more dangerous [this fall], the ice in some areas was very thin ... for a long time. In other years it would have been good, [but this year it has] hampered the safety of the ice. It has been [a] dangerous year, especially [where there are ocean] currents' $(\mathrm{H}$. Paniaq, Dec 2006)

Increasing physical danger of using the ice was compounded by the rising price of fuel used to power snowmobiles, with the price of unleaded gasoline increasing from $\sim \$ 0.90 \mathrm{l}^{-1}$ in 2004 to $\$ 1.20 \mathrm{l}^{-1}$ in November 2006 (prices here and below are in Canadian dollars). In Nunavut, the territorial government purchases fuel products in bulk once a year, and organizes delivery to communities where the fuel is stored until the next annual re-supply (http://cgs.gov.nu.ca/ 
en/petroleum-products). Price varies according to the cost of fuel at the time of purchase, and the price increase (or decrease) is announced in November each year. In November 2006, the price of fuel increased by $\sim \$ 0.10 \mathrm{l}^{-1}$ in Nunavut and, in combination with increasing commodity prices in general, affected how community members in Igloolik experienced and responded to climatic extremes (Fig. 5). Participants noted taking as little fuel (for snowmobiles) as possible when making hunting or recreational trips due to price. Redundancy is a key feature of Inuit adaptability and in previous research in Igloolik, community members noted taking more fuel than necessary to cover all eventualities (Ford et al. 2006b). Rising prices have reduced people's ability to make extra preparations, particularly among those with a low cash flow, eroding the safety net provided by redundancy. Indeed, participants drew attention to the increasing number of people running out of gasoline while hunting in 2006. For those without adequate land skills and/or equipment, such incidents are serious and can result in loss of life. Running out of gasoline can also have implications for the food system (Fig. 5). One elder explained an incident during fall: 'My 2 sons when [they were] hunting got stuck because [they ran out of] gas. They call[ed] me up. I brought the gas over to where they were ..... They had 8 caribou [but they were] all gone, [spoilt] because of the time.' An incident of this nature would not have been a problem for hunters with knowledge of how to cache and dry meat, but many of these skills are not being fully transferred and developed among younger generations. These examples demonstrate how the implications of a changing climate are mediated by interaction with socio-cultural conditions and change. Interestingly, adaptations including use of more fuel-efficient and less powerful hunting equipment in response to rising gasoline prices and climate adaptations are not being discussed locally.

\subsubsection{Adaptive capacity}

Despite the increased potential danger of using the ice in 2006, participants noted that the safety implications of sea ice extremes in fall 2006 were relatively minor compared to previous years. There were no injuries and equipment damage/loss was minimal. As documented in previous research in Igloolik, and elsewhere in Nunavut (Gearheard et al. 2006, Riewe \& Oakes 2006) and other Inuit regions of the Arctic (George et al. 2004), the accumulated experience of adapting to sea ice variability and extremes, and the detailed knowledge of sea ice processes held by the more mature and older hunters helped moderate the impacts of sea ice extremes. During early stages of ice formation, for example, focus group participants explained their vigilance in evaluating the condition of the ice, using visual clues and testing using a harpoon to judge safety and avoid dangerous areas. Other reported adaptations, enabled by local Inuit expertise, included avoiding travel until December and delaying travel to Baffin Island and the mainland until the ice was judged to be safe to use. The increasing use of safety equipment such as Global Positioning Systems

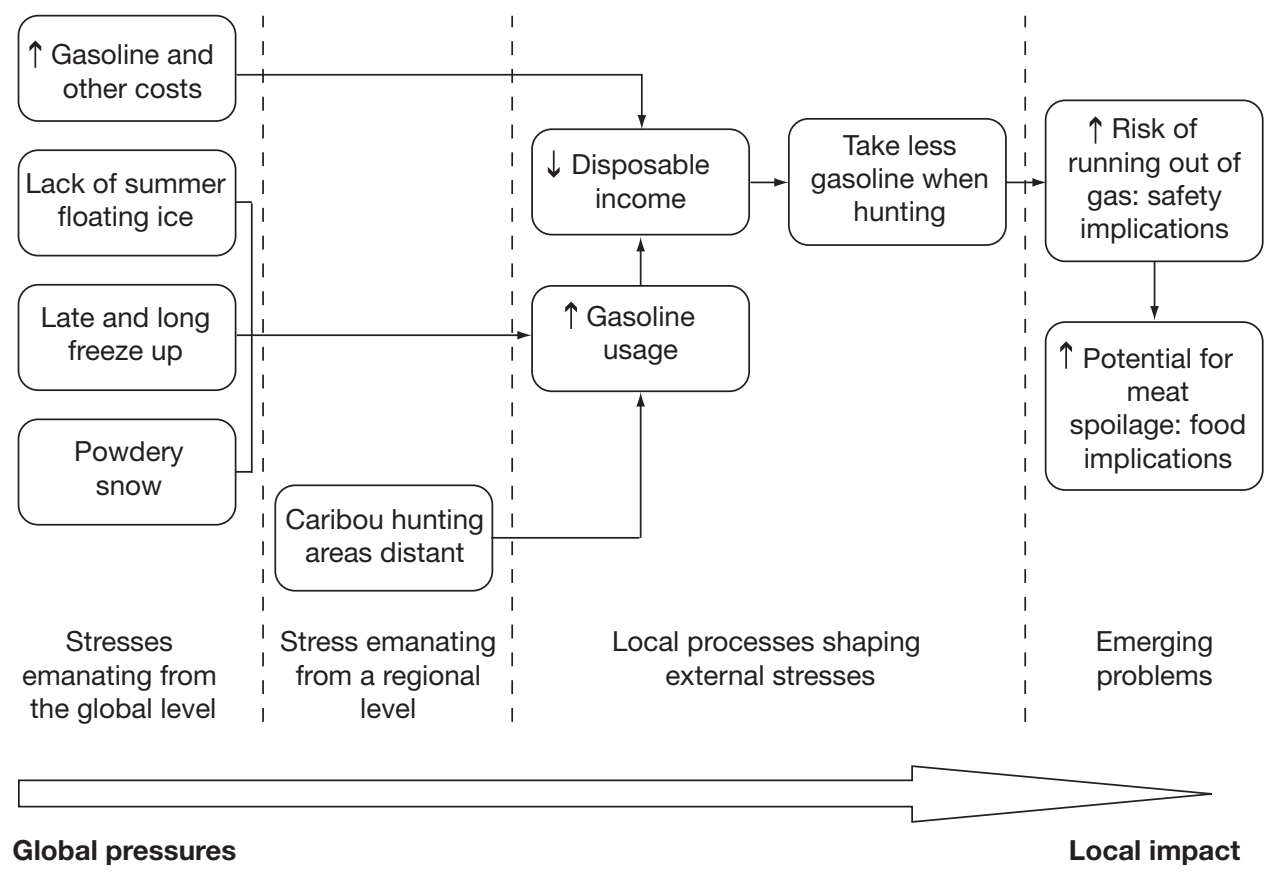

Fig. 5. Multiple stressors and the implications of sea ice conditions in 2006 
(GPS), satellite phones, and consultation of weather forecasts prior to traveling on the ice also helped to reduce the risks of using the ice, although negative impacts of these technologies on safety have also been noted elsewhere (Aporta \& Higgs 2005).

Local institutions also played an important role in moderating the risk burden in 2006, most notably the local Hunters and Trappers Organization (HTO) whose jurisdiction covers the general management of community harvesting including, but not limited to, the regulation of harvesting practices and techniques. In fall, the polar bear hunting season was opened by the HTO in early November when the ocean initially froze. Following local procedure, tags (i.e. permits) to hunt polar bears were distributed by drawing lots. Experienced hunters and elders, who make up the board of the HTO, noted early in the polar bear season the dangers of traveling on the ice and consequently stopped the hunt for $2 \mathrm{wk}$ (mid November - 1st December) until ice conditions improved. This corresponds to the $7 / 10$ ice coverage observed in CIS charts around the same time, as well as the temperature increase and heavy snowfall. Those with tags allocated prior to the ban were able to continue once the HTO re-opened the hunt, this being an important consideration given the importance of polar bear hunting both culturally and economically (see Wenzel 2005).

'The polar bear hunt was stopped because of the dangers. There was snow [on the ice] but underneath the snow there was open water and the elders thought that if the polar bear hunt was to go ahead it would be dangerous for the youth who didn't know the surrounding areas .... When the elders decided it was too dangerous, the elders got together and put a stop to it until they felt sure it was not a danger anymore.' (L. Uttak, Dec 2006)

Closure of the hunt reduced exposure to dangerous sea ice conditions, especially for younger hunters who are believed to be vulnerable to sea ice risks, and points to the wider importance of elders in underpinning adaptability. Those knowledgeable and experienced on the land or ice act as an 'institutional memory', maintaining and transmitting local knowledge and providing information during periods of change. Providing such guidance and information is considered an affirmation of Inuit identity, and many elders consider the safety of hunters their responsibility. It also supports the suggestion that flexible institutions that are close to the resources and receptive to environmental feedback stand a better chance of successful response to change than top-down, centralized management systems (Kofinas 2004, Armitage 2005, Armitage et al. 2008). The HTO, with its formal involvement of local elders and experienced hunters in decision making, was able to effectively and quickly respond to the dangerous ice conditions.

\subsubsection{Emerging adaptive capacity}

Adaptability in the face of sea ice conditions in fall 2006 contrasts with previous years in Igloolik, when serious incidents were reported and attributed to dangerous ice conditions (Fox 2002, Ford 2005, 2006a, Ford et al. 2006b). Analyses of the focus group data and previous interviews indicate a number of processes which appear to be moderating the effects of ice extremes in Igloolik.

Firstly, Igloolik Inuit have experienced and responded to changing ice conditions and increasing occurrence of extremes since the mid to late 1990s (Fox 2002, 2004, Laidler \& Ikummaq 2008). Experience with stress appears to be enabling social learning, whereby trial and error experience has developed and refined means of adapting. This is particularly important in helping reduce the dangers of using the ice in a changing climate. A good example in Igloolik is an incident involving focus group participant $H$. Ittusardjuat. In fall 2005, he described falling through the ice on his snowmobile on the way to char fishing lakes on the mainland. His satellite phone was in his sled and he was unable to access it to call for help, resulting in a long walk home in sub-zero temperatures. After this incident he now carries his phone in his parka for easy access in case of an accident. Other examples of social learning in Igloolik and elsewhere in the Canadian Arctic are documented in Ford et al. (2008a). Through individual experiences like this, and subsequent discussion over the local radio, with elders and experienced individuals, and with others in the community and while hunting, Inuit knowledge has evolved with changing sea ice and other environmental conditions. Indeed, the evolution of old and creation of new heuristics in response to change, defines the very nature of Inuit knowledge, which is developed and acquired through experiential and inter-generational learning (Wenzel 1999, Laidler 2006). This collective social memory, with accumulated experience in responding to sea ice extremes in a changing climate, framed individual practice and decision making in fall 2006 to moderate the increased risks of using the ice. There is local concern, however, that when today's elders pass away, many of the younger generations may not have the knowledge or skills to promote and conduct safe and successful hunting. From a climate change perspective, this could increase exposure sensitivity and reduce adaptive capacity to changing climatic conditions.

Secondly, increased climate variability and extremes are being accepted as the new norm in Igloolik. This contrasts with previous fieldwork between 2003 and 2005 when participants noted that the Arctic environment is naturally variable and that the late freeze-up and early break-up, unusual weather, and ice instabil- 
ity documented since the mid to late 1990s were manifestations of this variability (Ford et al. 2006b). It was commonly explained that 'things will get back to normal next year.' However, 2006 appears to signify a change in how Igloolik Inuit perceive and explain variability and extremes. Focus group participants described 2006 ice conditions as being reflective of human-induced climate change and expect the trend to continue into the future. This new realization is affecting preparations made before traveling and the hunting equipment taken on trips. In interviews conducted in 2004, and in interviews in the IOHP, for example, elders and experienced hunters noted the increased use of new technology in hunting but were skeptical of its benefits. During focus group discussions in 2006, the same participants argued that GPS and satellite phones were essential for safe hunting in light of changing climatic conditions, noting that many residents, both old and young, make use of these technologies. In this context, the endorsement of new technology by those experienced on the land is important, with young and/or inexperienced hunters often traveling with and seeking advice from these local experts before hunting.

\section{DISCUSSION}

Instrumental datasets and Inuit community members document anomalous sea ice conditions in 2006. Fall freeze-up was one of latest in the last $40 \mathrm{yr}$ and the summer open-water period was characterized by limited ice cover. Dimensions of vulnerability are evident in the food system, with sea ice conditions constraining people's ability to procure country food including seal, caribou and walrus, especially in summer and fall. While food sharing and hunting flexibility helped moderate some of these risks, these mechanisms were unable to fully cover the shortfall. For those dependent on the products of the hunt, switching to store-bought food was an unacceptable social and economic tradeoff; this group of Igloolik Inuit are more likely to be vulnerable to compromised food security if hunting access is further constrained with future climate change. For a growing population of young Inuit, the implications were less pronounced, with fewer younger generations being dependent upon hunting and the food it provides. Indeed, many youth indicate preferring store food and eating country food only when they are available. When country food access is limited, they have more flexibility to substitute food types. However, for young people who rely on country food to provide for their families, the erosion of certain skill sets is affecting their ability to hunt and bring back traditional food as the example of caribou spoilage indicates. Food system vulnerability in 2006 exceeded previous years when coping mechanisms largely maintained food system adaptability in the face of climatic stress. This indicates the significance of the extreme ice conditions in 2006, which were in many ways unprecedented. Non-climatic stresses, including increasing gasoline prices over time and the price increase in November 2006, also increased exposure sensitivity to sea ice extremes. The climate change literature has generally highlighted that such 'multiple exposures' are important in determining vulnerability to climate change (O'Brien \& Leichenko 2000, O'Brien \& Leichenko 2003, Liu et al. 2007, McLeman et al. 2008, Keskitalo 2008). Underlying food system vulnerabilities were also significant, mainly through their negative impact on household finances and ability to purchase store food, and are assessed in more detail elsewhere (Ford in press).

A combination of risk management, avoidance, and sharing strategies, facilitated by Inuit knowledge, flexible local institutions and sharing networks, enabled the moderation of increased physical risks of using the ice in fall 2006. In contrast to previous years, it was noted that while the ice was dangerous in fall, there were few accidents and/or damage to equipment. This appears to indicate increasing adaptive capacity over time and demonstrates that changing conditions can have positive impacts through social learning and innovation, even if the short-term effects are negative. The ability to learn from disturbance, the acceptance of uncertainty, and the flexibility of local institutions are widely believed to underpin adaptable and resilient systems in a variety of geographic and sociocultural contexts (Berkes et al. 2003, Folke et al. 2003, Tompkins \& Adger 2004, Berkes 2007, Armitage et al. 2008). Thus, sea ice conditions in 2006 need to be situated in the context of changing sea ice and other environmental conditions documented in Igloolik since the mid to late 1990s. Through trial and error experience of these changes, innovation, development of new heuristics alongside memory of traditional ways, and acceptance of new uncertainty in a changing climate, Inuit knowledge of the ice appears to be evolving to reframe decision making in light of changing conditions.

The unprecedented sea ice conditions in summer and fall 2006 correspond in many respects to predictions of altered ice conditions with climate change. By mid century, for example, it is predicted that freeze-up will occur in mid to late November on a regular basis, the ice-free open-water season will be longer, and the ice will thin and be more dynamic throughout the year (Dumas et al. 2006). Moreover, anomalous climaterelated conditions will increasingly become the norm in Igloolik and throughout Arctic Canada, with climate 
change (ACIA 2005, Furgal \& Prowse 2008). By focusing on vulnerability and adaptability of Igloolik Inuit to sea ice conditions in 2006, this paper provides important insights into the potential local implications of future sea ice change and a baseline from which to examine how future climate change might generally affect Inuit communities, these insights being increasingly recognized in the climate change literature (Adger et al. 2006, Belliveau et al. 2006, Riewe \& Oakes 2006, Liu et al. 2007, Thomas et al. 2007, Keskitalo 2008, McLeman et al. 2008). We demonstrate that vulnerability to a specific climate-related event (e.g. lack of summer sea ice, late freeze-up) can be exacerbated or moderated by changes in other climatic conditions and non-climatic stresses. A late and slow freeze-up on its own, for example, is not necessarily problematic; in 2006, a combination of an unsuccessful summer walrus hunt, rising gasoline prices, and longer-term sociocultural stresses, increased exposure sensitivity and constrained adaptive capacity to sea ice extremes. We illustrate that vulnerable groups often emerge due to the synergistic interaction of climatic and non-climatic stresses, which combine to overwhelm adaptability. We highlight how certain groups and sectors are at greater risk than others, depending on their livelihoods and socio-economic characteristics. The food system, for instance, is sensitive to climatic extremes, with those relying on country food for a large portion of their diet being more vulnerable to changing food access and availability. This study also re-affirms the adaptability of Inuit, with changing conditions stimulating social and institutional learning. It is of particular concern, however, that a decreasing number from younger generations are learning the land-based skills and knowledge which underpin adaptive capacity (Ford et al. 2007).

These insights have important policy implications, particularly for reducing vulnerability to 'climate crises'. During periods of climate-driven stress, targeting nonclimatic drivers of vulnerability offers a strategic entry point for policy to reduce the risks. In 2006, for example, emergency intervention to subsidize gasoline prices during summer and fall would have relieved the burden of having to travel further to hunt due to ice conditions. Assistance to improve accessibility to store food (e.g. food credits, expansion of the local food bank, improved food mail system) for high-risk groups during summer and fall would also have increased adaptability, enabling those with low income and limited ability to procure country food to maintain food access (see Myers et al. 2004). Educational/informational territory-wide campaigns and/or incentives are also required to help hunters make informed choices when buying hunting equipment. In the context of rising gasoline prices and climate adaptations, the cur- rent purchasing trend towards high-powered snowmobiles and outboard boat motors is maladaptive in many ways, although high-powered machines allow quick access to land if problems are encountered (see Aporta 2004, Ford 2008 for discussion of hunting technology and safety implications). Strengthening other sources of adaptive capacity is also important. Inuit knowledge, for example, plays a crucial role in underpinning community adaptability and reducing sensitivity to climatic risks, yet studies indicate that in the absence of support, the transmission of important hunting skills is at risk (Takano 2004, Duerden \& Beasley 2006, Ford et al. 2007). Efforts to encourage and support the reestablishment of outpost camps located closer to known concentrations of wildlife would reduce the need for long-distance travel over increasingly dangerous sea ice, and increase access to wildlife at times of the year which are becoming increasingly difficult. Moreover, outpost camps could supply meat to Igloolik on a regular basis, buffering fluctuations in meat availability. Potential climate change adaptation strategies for Nunavut are discussed in greater detail by Ford et al. (2007).

\section{CONCLUSIONS}

There is strong evidence that human-induced climate change has been underway for at least the last decade in Arctic regions. Climate models indicate accelerated climate change in the future, with many current climate risks projected to increase in magnitude and frequency. The potential negative implications of climate change for Northern residents and the urgency of developing policy to moderate and reduce impacts has increased the demand for studies assessing climate change vulnerability. Retrospective studies offer one way to learn about the causal processes shaping climate change vulnerability and can establish a baseline from which to conduct prospective studies. In this research, the ice conditions of summer and fall 2006 enabled us to explore aspects of humanenvironment interactions which determine how Inuit experience and respond to climatic extremes. What emerges is a complex story of interacting climatic and non-climatic stresses shaping vulnerability to sea ice extremes, influenced by processes originating at multiple spatial and temporal scales. These findings are consistent with human dimensions of climate change research elsewhere in the Arctic and other geographic contexts, which has located vulnerable groups in a nexus of interacting social, cultural, economic, and biophysical stresses. Moreover, in the context of Canadian Inuit communities, climate change will affect human systems already under significant stress. High baseline food insecurity, for example, will likely increase vul- 
nerability to climatic risks. This case study also appears to re-affirm the adaptability of Inuit to climatic stress and highlights that adaptability can increase over time as climate change impacts are experienced. Indeed, it suggests that, as far as physical risk is concerned, the impacts of climate change may be less pronounced than once thought.

The findings presented in this paper are part of a broader project seeking to characterize and understand processes shaping climate change vulnerability in the Arctic using detailed community case studies (International Polar Year CAVIAR project). Continued monitoring of community experience and responses to variability, extremes and change of in Igloolik will allow recent observations of emerging adaptability and vulnerability to be tested as the social and biophysical environment continues to change. Moreover, case studies in other communities will permit a greater understanding of the extent to which trends in Igloolik are applicable elsewhere.

Acknowledgements. We thank the community members and local organizations in Igloolik for their support and collaboration which made this research possible, the local researchers and the Igloolik branch of the Nunavut Research Institute (L. Otak) for facilitating communication and knowledge exchange between the researchers and local experts. Focus groups were in compliance with ethical protocols of McGill University, and were conducted under Nunavut Research License \#0203204N-M. Financial support for this research was provided by: a Climate Change Impacts and Adaptation Program (CCIAP) grant from Natural Resources Canada, the Social Sciences and Humanities Research Council, ArcticNet Theme 4.2 and the Nasivvik Centre for Inuit Health and Changing Environments. Ongoing research support is provided by the International Polar Year CAVIAR project. We also thank L. B. Ford for producing Fig. 1 and commenting on previous drafts of this article, S. Kowal of the University of Toronto and A. Gagnon of the Environmental Research Institute at North Highland College for help in analyzing the sea ice trends, and B. Smit of the University of Guelph for contributions to fieldwork and support in Igloolik. Two anonymous reviewers provided constructive feedback.

\section{LITERATURE CITED}

ACIA (2005) Arctic climate impacts assessment-Scientific report. Cambridge University Press, Cambridge. www.acia. uaf.edu/pages/scientific.html

Adger WN, Paavola J, Huq S, Mace MJ (2006) Fairness in adaptation to climate change. MIT Press, Cambridge, MA

Anderson LE, Garlich-Miller J (1994) Economic analyses of the 1992 and 1993 summer walrus hunts in northern Foxe Basin, Northwest Territories. Department of Fisheries and Oceans, Central and Arctic Region, Winnipeg

Aporta C (2002) Life on the ice: understanding the codes of a changing environment. Polar Rec (Gr Brit) 38:341-354

Aporta C (2004) Routes, trails and tracks: trail breaking among the Inuit of Igloolik. Inuit Stud 28:9-38

Aporta C, Higgs E (2005) Satellite culture: Global Positioning Systems, Inuit wayfinding, and the need for a new account of technology. Curr Anthropol 46:729-753

Armitage DR (2005) Community-based Narwhal management in Nunavut, Canada: change, uncertainty, and adaptation. Soc Nat Resour 18:715-731

Armitage D, Marschke M, Plummer R (2008) Adaptive comanagement and the paradox of learning. Glob Environ Change 18:86-98

Barber D, Iacozza J (2004) Historical analysis of sea ice conditions in M'Clintock Channel and Gulf of Boothia, Nunavut: implications for ringed seal and polar bear habitat. Arctic 57:1-14

Bates P (2007) Inuit and scientific philosophies about planning, prediction, and uncertainty. Arctic Anthropol 44:87-100

Belliveau S, Smit B, Bradshaw B (2006) Multiple exposures and dynamic vulnerability: evidence from the grape and wine industry in the Okanagan Valley, British Columbia, Canada. Glob Environ Change 20:1-21

Berkes F (2007) Understanding uncertainty and reducing vulnerability: lessons from resilience thinking. Nat Hazards 41:283-295

Berkes F, Jolly D (2001) Adapting to climate change: socialecological resilience in a Canadian Western Arctic community. Conserv Ecol 5:18 [online] www.consecol.org/ vol5/iss2/art18/

Berkes F, Colding J, Folke C (2003) Navigating socialecological systems: building resilience for complexity and change. Cambridge University Press, Cambridge

Berrang Ford L, MacLean D, Gyorkos T, Ford J, Ogden N (2009) Climate change and malaria in Canada: a systems approach. Interdiscipl Perspect Infect Dis 2009:1-13

Chan HM, Fediuk K, Hamilton SE, Rostas L and others (2006) Food security in Nunavut, Canada: barriers and recommendations. Int J Circumpolar Health 65:416-431

Corell RW (2006) Challenges of climate change: an Arctic perspective. Ambio 35:148-152

Cruikshank J (2001) Glaciers and climate change: perspectives from oral tradition. Arctic 54:372-393

Duerden F (2004) Translating climate change impacts at the community level. Arctic 57:204-212

Duerden F, Beasley E (2006) Assessing community vulnerabilities to environmental change in the Inuvialuit region. In: Riewe $\mathrm{R}$, Oakes J (eds) Climate change: linking traditional and scientific knowledge. Aboriginal Issues Press, Winnipeg, p 81-94

> Dumas J, Flato G, Brown RD (2006) Future projections of landfast ice thickness and duration in the Canadian Arctic. J Clim 19:5175-5189

Folke C, Colding J, Berkes F (2003) Building resilience for adaptive capacity in social-ecological systems. In: Berkes F, Colding J, Folke C (eds) Navigating social-ecological systems: building resilience for complexity and change. Cambridge University Press, Cambridge, p 352-387

Ford JD (2005) Living with change in the Arctic. World Watch September/October, p 18-21

Ford JD (2006) Vulnerability to climate change in Arctic Canada. PhD thesis, University of Guelph

Ford JD (2008) Climate, society, and natural hazards: changing hazard exposure in two Nunavut communities. Northern Rev 28:51-71

Ford JD (in press) Vulnerability of Inuit food systems to food insecurity as a consequence of climate change: a case study from Igloolik, Nunavut. Reg Environ Change, doi 10.1007/s10113-008-0060-x

Ford JD, Smit B (2004) A framework for assessing the vulnerability of communities in the Canadian Arctic to risks associated with climate change. Arctic 57:389-400

Ford JD, Smit B, Wandel J (2006a) Vulnerability to climate 
change in the Arctic: a case study from Arctic Bay, Canada. Glob Environ Change 16:145-160

Ford JD, Smit B, Wandel J, MacDonald J (2006b) Vulnerability to climate change in Igloolik, Nunavut: what we can learn from the past and present. Polar Rec 42:127-138

Ford JD, Pearce T, Smit B, Wandel J, Allurut M, Shappa K, Ittusujurat H, Qrunnut K (2007) Reducing vulnerability to climate change in the Arctic: the case of Nunavut, Canada. Arctic 60:150-166

Ford JD, Pearce T, Gilligan J, Smit B, Oakes J (2008a) Climate change and hazards associated with ice use in Northern Canada. Arct Antarct Alp Res 40:647-659

Ford JD, Smit B, Wandel J, Allurut M, Shappa K, Qrunnut K, Ittusujurat $\mathrm{H}$ (2008b) Climate change in the Arctic: current and future vulnerability in two Inuit communities in Canada. Geogr J 174:45-62

Fox S (2002) These are things that are really happening: Inuit perspectives on the evidence and impacts of climate change in Nunavut. In: Krupnik I, Jolly D (eds) The Earth is faster now: indigenous observations of climate change. Arctic Research Consortium of the United States, Fairbanks, Alaska, p 12-53

Fox S (2004) When the weather is Uggianaqtuq: linking Inuit and scientific observations of recent environmental changes in Nunavut, Canada. PhD Thesis, University of Colorado, Boulder

Furgal C, Prowse T (2008) Northern Canada. In: Lemmen D, Warren F, Bush E, Lacroix J (eds) From impacts to adaptation: Canada in a changing climate 2007. Natural Resources Canada, Ottawa, p 57-118

Furgal C, Seguin J (2006) Climate change, health, and vulnerability in Canadian northern aboriginal communities. Environ Health Perspect 114:1964-1970

Furgal C, Fletcher C, Dickson C (2006) Ways of knowing and understanding: towards the convergence of traditional and scientific knowledge of climate change in the Canadian North. Environment Canada, Toronto, ON

Fussel HM, Klein RTJ (2006) Climate change vulnerability assessments: an evolution of conceptual thinking. Glob Environ Change 75:301-329

Gagnon AS, Gough WA (2005a) Trend and variability in the dates of ice freeze-up and break-up over Hudson Bay and James Bay. Arctic 58:370-382

Gagnon AS, Gough WA (2005b) Climate change scenarios for the Hudson Bay region: an intermodel comparison. Clim Change 69:269-297

Gearheard S, Matumeak W, Angutikjuaq I, Maslanik J and others (2006) 'It's not that simple': a collaborative comparison of sea ice environments, their uses, observed changes, and adaptations in Barrow, Alaska, USA, and Clyde River, Nunavut, Canada. Ambio 35:203-211

George JC, Huntington H, Brewster K, Eicken H, Norton DW, Glenn R (2004) Observations on shorefast ice dynamics in Arctic Alaska and the responses of the Inupiat hunting community. Arctic 57:363-374

Glantz M (ed) (1988) Societal responses to regional climatic change: forecasting by analogy. Westview Press, Boulder, $\mathrm{CO}$

Glantz M (1996) Currents of change: El Niño's impact on climate and society. Cambridge University Press, Cambridge

Gough WA, Cornwell AR, Wolfe E (2004) Trends in seasonal sea ice duration in southwestern Hudson Bay. Arctic 57: $142-148$

Hamilton LC, Lyster PA, Otterstad O (2000) Social change, ecology and climate in 20th century Greenland. Clim Change 47:193-211

Hamilton LC, Brown BC, Rasmussen RO (2003) West Green- land's cod-to-shrimp transition: local dimensions of climatic change. Arctic 56:271-282

Holland MM, Bitz CM, Tremblay B (2006) Future abrupt reductions in the summer Arctic sea ice. Geophys Res Lett 33: L23503, doi: 10.1029/2006GL028024

Hovelsrud GK, McKenna M, Huntington HP (2008) Marine mammal harvests and other interactions with humans. Ecol Appl 18:S135-S147 (Supplement)

> Huntington H, Hamilton LC, Nicholson C, Brunner R, Lynch A, Ogilvie AEJ, Voinov A (2007) Toward understanding the human dimensions of the rapidly changing arctic system: insights and approaches from five HARC projects. Reg Environ Change 7:173-186

Huntington H, Hamilton LC, Nicholson C, Brunner R, Lynch A, Ogilvie AEJ, Voinov A (2008) Toward understanding the human dimensions of the rapidly changing arctic system: insights and approaches from five HARC projects. Reg Environ Change 7:173-186 doi: 10.1007/s10113-0070038-0

IPCC (2007a) Climate change 2007: impacts, adaptation and vulnerability. Contribution of Working Group II to the Fourth Assessment Report of the Intergovernmental Panel on Climate Change. Cambridge University Press, Cambridge

IPCC (2007b) Climate change 2007: the physical science basis. Contribution of Working Group I to the Fourth Assessment Report of the Intergovernmental Panel on Climate Change. Cambridge University Press, Cambridge

Johannessen OM, Bengtsson L, Miles MW, Kuzmina SI and 8 others (2004) Arctic climate change: observed and modelled temperature and sea ice variability. Tellus 56A: $328-341$

Kerr RA (2007) Climate change. Is battered Arctic sea ice down for the count? Science 318:33-34

Keskitalo ECH (2008) Climate change and globalization in the Arctic: an integrated approach to vulnerability assessment. Earthscan, London, p 272

Kofinas GP (2004) A research plan for the study of rapid change, resilience, and vulnerability in social-ecological systems of the Arctic. Common Property Resour Digest 73:1-10

Krupnik I, Jolly D (2002) The Earth is faster now: indigenous observations of climate change. Arctic Research Consortium of the US, Fairbanks, Alaska

Kuhnlein HV, Receveur O (2007) Local cultural animal food contributes high levels of nutrients for Arctic Canadian indigenous adults and children. J Nutr 137:1110-1114

Kuhnlein HV, Soueida R, Receveur O (1996) Dietary nutrient profiles of Canadian Baffin Island Inuit differ by food source, season, and age. J Am Diet Assoc 96:155-162

Laidler GJ (2006) Inuit and scientific perspectives on the relationship between sea ice and climatic change: the ideal complement? Clim Change 78:407-444

Laidler GJ, Elee P (2008) Human geographies of sea ice: freeze/thaw processes around Cape Dorset, Nunavut, Canada. Polar Rec 44:51-76

Laidler GJ, Ikummaq T (2008) Human geographies of sea ice: freeze/thaw processes around Igloolik, Nunavut, Canada. Polar Rec (Gr Brit) 44:127-153

Laidler GJ, Dialla A, Joamie E (2008) Human geographies of sea ice: freeze/thaw processes around Pangnirtung, Nunavut, Canada. Polar Rec (Gr Brit) 44:335-361

Laidler GJ, Ford J, Gough WA, Ikummaq T and others (2009) Travelling and hunting in a changing Arctic: assessing Inuit vulnerability to sea ice change in Igloolik, Nunavut. Clim Change (online)

Leary NA, Adejuwon J, Barros V, Burton I, Kulkarni J, Lasco 
R (eds) (2007) Climate change and adaptation. Earthscan, London

Liu J, Dietz T, Carpenter SR, Alberti M and others (2007) Complexity of coupled human and natural systems. Science 317:1513-1516

McCarthy JJ, Martello ML, Corell R, Selin NE and others (2005) Chapter 17. Climate change in the context of multiple stressors and resilience. Arctic Climate Impact Assessment. Cambridge University Press, NY, p 946-988

McLeman R, Mayo D, Strebeck E, Smit B (2008) Drought adaptation in rural eastern Oklahoma in the 1930s: lessons for climate change adaptation research. Mitig Adapt Strategies Glob Change 13:379-400

Meier WN, Stroeve J, Gearheard S (2006) Bridging perspectives from remote sensing and Inuit communities on changing sea ice cover in the Baffin Bay Region. Ann Glaciol 44:433-438

Moore GKW (2006) Reduction in seasonal sea ice concentration surrounding southern Baffin. Geophys Res Lett 33: L20501, doi: 10.1029/2006GL027764

Moore SE, Huntington HP (2008) Arctic marine mammals and climate change: impacts and resilience. Ecol Appl 18: S157-S165 (Supplement)

Myers H, Powell S, Duhaime G (2004) Setting the table for food security: policy impacts in Nunavut. Can J Native Stud 24:425-445

Nadasdy P (2003) Reevaluating the co-management success story. Arctic 56:367-380

Nelson R (1969) Hunters of the northern ice. University of Chicago Press, Chicago, IL

Nickels S, Furgal C, Buell M, Moquin H (2006) Unikkaaqatigiit-Putting the human face on climate change: perspectives from Inuit in Canada. Inuit Tapiriit Kanatami, Ottawa

Norton DW, Gaylord AG (2004) Drift velocities of ice floes in Alaska's northern Chukchi sea flaw zone: determinants of success by spring subsistence whalers in 2000 and 2001. Arctic 57:347-362

O'Brien KL, Leichenko RM (2000) Double exposure: assessing the impacts of climate change within the context of economic globalization. Glob Environ Change 10:221-232

O'Brien KL, Leichenko RM (2003) Winners and losers in the context of global change. Ann Assoc Am Geogr 93:89-103

Overland JE, Wang M (2007) Future regional Arctic sea ice declines. Geophys Res Lett 34:L17705, doi: 10.1029/2007 GL030808

Peters EJ (2003) Views of traditional ecological knowledge in co-management bodies in Nunavik, Quebec. Polar Rec 39:49-60

Riedlinger D, Berkes F (2001) Contributions of traditional knowledge to understanding climate change in the Cana-

Editorial responsibility: Joan Kleypas,

Boulder, Colorado, USA dian Arctic. Polar Rec 37:315-328

Riewe R, Oakes J (eds) (2006) Climate change: linking traditional and scientific knowledge. Aboriginal Issues Press, Winnipeg

> Schröter D, Polsky C, Patt AG (2005) Assessing vulnerabilities to the effects of global change: an eight step approach. Mitig Adapt Strategies Glob Change 10:573-595

Smit B, Pilifosova O (2003) From adaptation to adaptive capacity and vulnerability reduction. In: Smith J, Klein RTJ, Huq S (eds) Climate change, adaptive capacity, and development. Imperial College Press, London, p 9-28

Smit B, Wandel J (2006) Adaptation, adaptive capacity, and vulnerability. Glob Environ Change 16:282-292

Smit B, Hovelsrud G, Wandel J (2008) Community adaptation and vulnerability in Arctic Regions. Occasional Paper No. 28, Department of Geography, University of Guelph

StatsCanada (2006) The 2006 Census. Statistics Canada, Ottawa. http://www12.statcan.ca/census-recensement/ 2006/dp-pd/prof/92-591/details/Page.cfm?Lang=E\&Geo1= CSD\&Code1 $6204012 \&$ Geo $2=$ PR\&Code $2=62 \&$ Data $=$ Count $\&$ SearchText=Igloolik \&SearchType=Begins $\&$ SearchPR $=01$ $\& \mathrm{~B} 1=\mathrm{All} \&$ Custom $=$

- Stroeve J, Serreze M, Fetterer T, Arbetter W, Meier J, Maslanik J, Knowlees K (2005) Tracking the Arctic's shrinking ice cover: another extreme minimum in 2004. Geophys Res Lett 32:L04501, doi: 10.1029/2004GL021810

Stroeve J, Holland MM, Meier WN, Scambos T, Serreze M (2007) Arctic sea ice decline: faster than forecast. Geophys Res Lett 34:L09501, doi: 10.1029/2007GL029703

Takano T (2005) Connections with the land: land skills courses in Igloolik, Nunavut. Ethnography 6:463-486

> Thomas D, Twyman C, Osbahr H, Hewitson B (2007) Adaptation to climate change and variability: farmer responses to intra-seasonal precipitation trends in South Africa. Clim Change 83:301-322

Tompkins EL, Adger WN (2004) Does adaptive management of natural resources enhance resilience to climate change? Ecol Soc 9:10 [online] www.ecologyandsociety.org/vol9/ iss2/art10

Turner BL II, Kasperson RE, Matson PA, McCarthy J and others (2003) A framework for vulnerability analysis in sustainability science. Proc Natl Acad Sci USA 100: 8074-8079

van Aalst MK, Cannon T, Burton I (2008) Community level adaptation to climate change: the potential role of participatory community risk assessment. Glob Environ Change 18:165-179

Wenzel G (1999) Traditional ecological knowledge and Inuit: reflections on TEK research and ethics. Arctic 52:113-124

Wenzel G (2005) Nunavut Inuit and polar bear: the cultural politics of the sports hunt. Senri Ethnol Stud 67:363-388

Submitted: June 5, 2008; Accepted: September 22, 2008

Proofs received from author(s): January 17, 2009 